\title{
State Responses to the Gold Rush in the Andes (2004-2018): The Politics of State Action (and Inaction)
}

\author{
Viviana Baraybar Hidalgo ${ }^{1}$ (D) $\cdot$ Eduardo Dargent $^{2}$
}

Published online: 1 September 2020

(C) The Author(s) 2020

\begin{abstract}
Despite many similarities, the gold rush that hit the Andean countries in 2004 elicited different state responses in Bolivia, Colombia, and Peru. Initially, there was a lack of enforcement of regulations towards informal mining, but eventually Colombia (2009) and later Peru (2011) enforced regulations with mixed results. Bolivia, on the other hand, has not enforced such regulations. At first, this may appear to be a matter of state capacity; however, a closer look uncovers different motivations behind these state actions (and inaction). We propose that the nature of social actors (or the lack of social actors) who profited from the gold boom, along with international and domestic pressures, are a crucial determinant of these different government responses. We explore this proposal through an analysis of the cases before and during the gold rush using a mix of archival research and interviews with key government actors. These findings allow us to distinguish empirically between forms of state inaction — standoff and forbearance — with distinct political consequences.
\end{abstract}

Keywords State response $\cdot$ State capacity $\cdot$ Forbearance $\cdot$ Stand-off · Gold rush · Andean countries

From 2004 onwards, mineral prices rose to record highs, providing Latin American states with a windfall in resources. This commodity boom triggered a gold rush in

Electronic supplementary material The online version of this article (https://doi.org/10.1007/s12116-02009314-5) contains supplementary material, which is available to authorized users.

Viviana Baraybar Hidalgo

viviana.baraybarhidalgo@nuffield.ox.ac.uk

Eduardo Dargent

edargent@pucp.edu.pe

1 Nuffield College and Department of Politics and International Relations, University of Oxford, Oxford, England

2 Social Science Department, Pontificia Universidad Católica del Perú, Lima, Peru 
several countries. In 2012, gold cost US\$ 1669 per ounce, $360 \%$ more than in 2004, when the boom began. ${ }^{1}$ Although the price has since fallen, it remains above US\$ 1000 and still provides strong incentive for citizens to become small miners, oftentimes in an informal capacity. Latin American countries have a long history of cooperation and conflict with artisanal gold miners, with state governance strategies ranging from formalization to penalization. Artisanal gold miners are usually located in geographical areas with limited state presence, making it difficult for governments to regulate extraction and partly explaining the high degree of informality in these activities. However, gold rushes make regulations even more difficult to enforce. The recent boom precipitated informal gold mining, entitlement conflicts, forced labor, human trafficking, transnational exporting mafias, and money laundering, among other unlawful or transgressional activities. ${ }^{2}$

Despite similar effects, there are clear differences in how three Andean countriesBolivia, Colombia, and Peru-responded to the challenge of the gold rush. In these countries, there were three types of state approaches to regulating and penalizing growing informal, small-scale mining: two involving state inaction (standoff and forbearance) and one involving state action (enforcement). In Colombia, the state did not initially prioritize the enforcement of small gold mining regulations, choosing instead to "stand off" and continue its weak formalization policies. This position changed around 2009-2010, when the government implemented stricter formalization and securitization policies. In Peru, the state likewise made no major changes to its earlier standoff policies before gradually moving towards weak control. Eventually, in 2011, it implemented a more comprehensive enforcement strategy involving formalization and penalization. In Bolivia, new, small gold mining cooperatives joined the established, politically active ones. Although these new cooperatives were also informal and committed many environmental violations, the government largely forbore its duty to enforce regulations during the gold rush.

What explains these different state responses to a common challenge within a similar timeframe? We propose that these different state responses and their variations across time were fundamentally conditioned by the nature of the social actors (or the lack of social actors) who profited from the gold boom. Political and institutional processes, sometimes predating the gold rush by decades, conditioned the types of social actors who profited from high gold prices during the boom in each country. These actors, alongside international and domestic pressures, were crucial determinants of the different government responses.

In Colombia, gold attracted and fueled long-established violent actors, adding security concerns to internationally ubiquitous environmental pressures. This overlap with an ongoing conflict explains why the Colombian state treated the gold rush as a security issue. However, since the link between armed groups and small-scale gold mining was not always clear, the state initially opted for a standoff approach. In Peru, the lack of pre-existing organized political or violent actors in small-scale mining resulted in a fragmented gold rush, giving the government more options for dealing with the phenomenon. When the state eventually enforced formalization and

\footnotetext{
${ }^{1}$ Poveda 2015a, 6.

2 Devisscher 2008: 20-24; Ashe 2012; Cremers et al. 2013; Amazon Conservation Association 2014; SPDA (Sociedad Peruana De Derecho Ambiental). 2015.
} 
Table 1 State response, motivations, and observable implications

\begin{tabular}{|c|c|c|}
\hline $\begin{array}{l}\text { State } \\
\text { response }\end{array}$ & Main motivation & Observable implications \\
\hline Forbearance & Political gains & $\begin{array}{l}\text { - Inaction against violators of small-scale mining } \\
\text { regulations }\end{array}$ \\
\hline Bolivia & & $(2004-2016)$ \\
\hline $\begin{array}{l}\text { - State } \\
\text { actions to } \\
\text { support } \\
\text { other state } \\
\text { policies } \\
\text { that } \\
\text { promote }\end{array}$ & $\begin{array}{l}\text { small-scale gold extraction and limit } \\
\text { enforcement }\end{array}$ & \\
\hline $\begin{array}{l}\text { Standoff } \\
\text { Colombia }\end{array}$ & $\begin{array}{l}\text { No prioritization due to political } \\
\text { disinterest and/or cost prevention }\end{array}$ & $\begin{array}{l}\text { - Inaction against violators of small-scale mining } \\
\text { regulations }\end{array}$ \\
\hline $\begin{array}{l}\text { - No actions } \\
\text { to support } \\
\text { or erode } \\
\text { formal } \\
\text { and } \\
\text { informal }\end{array}$ & Peru (2004-2010) & $\begin{array}{l}\text { (2004-2008) } \\
\text { institutions that affect gold extraction }\end{array}$ \\
\hline Enforcement & $\begin{array}{l}\text { Colombia: state actors' security } \\
\text { concerns, domestic and international } \\
\text { pressures }\end{array}$ & $\begin{array}{l}\text { - Coordinated action against violators of small-scale } \\
\text { mining regulations }\end{array}$ \\
\hline $\begin{array}{l}\text { Colombia } \\
\text { (2009-) }\end{array}$ & $\begin{array}{l}\text { Peru: Domestic and international } \\
\text { pressures }\end{array}$ & $\begin{array}{l}\text { - Other state actions to regulate and limit informal } \\
\text { gold extraction }\end{array}$ \\
\hline $\begin{array}{l}\text { Peru } \\
\qquad(2011-)\end{array}$ & & \\
\hline
\end{tabular}

penalization measures, it was largely due to cumulative international and domestic pressures. In Bolivia, the power and political relevance of cooperatives - pre-existing social organizations used as institutional vehicles by those interested in exploiting the mineral-compelled the state to refrain from enforcement and collaborate with these actors. Table 1 presents these trajectories, our explanation for the cases, and general observable implications for distinguishing between different state responses.

According to Eaton, ${ }^{3}$ a "most similar systems" comparative research design enables the exploration of determinants of state response in developing countries. An exogenous shock, the gold rush, impacted Bolivia, Colombia, and Peru-three middleincome Andean countries producing three distinct state responses. According to the 2017 Artisanal and Small-Scale Mining Knowledge Sharing Archives, ${ }^{4}$ the four countries with the largest small-scale miner populations in South America are Brazil $(467,500)$, Colombia $(385,000)$, Bolivia $(170,000)$, and Peru $(110,000)$. These countries are broadly similar in their state capacity levels and in terms of the general regulations that limit informal mining and promote environmental protection. In the

\footnotetext{
${ }^{3}$ Eaton 2012, 650

${ }^{4}$ Intergovernmental Forum on Mining, Minerals, Metals and Sustainable Development 2017 
examined cases, small-scale gold extraction was a long-established activity that became more salient with the gold rush. In addition, the three countries faced similar international pressures to respond to the damaging effects of the gold rush on the environment and its linkages with transnational crime. Given these similarities, the comparative analysis allows us to highlight the crucial role that social actors-cooperatives in Bolivia and violent actors in Colombia - play in determining how middle-income countries react to social and economic challenges.

In order to document these state responses and the reasons that explain their variation across cases and over time within the same cases, we conducted interviews, reviewed official documents (including official releases by NGOs and state institutions such as the Ministries of the Interior, Environment, and Mining), and analyzed both external reports from organizations like the SPDA and press reports from the main newspapers in each country. Additionally, we documented variations in state action in Peru-where, we argue, the more varied response is likely due to the absence of strong social actors - through fieldwork in two gold-extracting centers (Madre de Dios and Puno).

We use reports both from international organizations like the SPDA and the CEDLA among others, previous work conducted by other researchers, and news reports for the main journals in each country for three main purposes. First, these reports allowed us to reconstruct the history of gold mining and the role social actors played on this history in our three cases. Second, we used them as a complement for our government sources. We used several official communicates and decrees of government action on informal gold mining and used the aforementioned reports to complement this official information and to track different types of evaluations (the government one and an external one) of the policies implemented. Finally, the reports allowed us to identify some of the key actors of the phenomenon, which aided in our goal of reconstructing the development of gold mining in relation to social actors and the consequent government policy decisions.

When it comes to interviews, we use them for two goals which cannot be easily achieved using the other sources. First, in the cases of Colombia and Peru, we use them to establish the logic driving the decision to change the state's response to gold mining, and to establish the logic of forbearing the change in the case of Bolivia. We therefore rely on interviews with key decision makers, namely high-ranking government officials. The criterion to select these interviews was relevance. We are interested in tracing high-stakes, elite-driven processes that involved a small number of actors in the upper echelons of each national administration. This naturally limits the pool of potentially relevant interviewees. Put differently, and following the advice of process tracing methodologists, we were not looking for a representative sample to establish "average" opinions among policy makers, but actors with inside-knowledge of the decisions in question (Tansey 2007). In the three cases, we successfully approached the relevant decision makers, previously identified using secondary sources. We asked them about the general government position regarding informal gold mining, the main policies implemented, and the obstacles they faced in the implementation. Given that they spoke on the record to researchers, they did not previously know these actors may have refrained from disclosing relevant information or true motives. However, as we show in the case studies, they answer key questions and were candid and to the point of revealing decision-making logics that did not necessarily portray them in a positive 
light. This reduces concerns about social desirability bias. Second, we use interviews with experts, and key members of civil society (indigenous communities, local NGOs, and the ex-members of cooperatives) for background. We approached these contacts because of their general expertise in the three cases. Evidence from these interviews is indirect and more speculative but instrumental in helping us make sense of the data extracted from documentary sources [for more details see Online Appendix A].

Our findings suggest that two of the main alternative explanations did not fully explain these trajectories. First, state capacity is frequently cited to explain effective and ineffective state responses to challenges. This theory would anticipate a more capable Colombia to react proactively and a weak Bolivia to be overwhelmed, with Peru's response falling somewhere in between. State capacity is certainly relevant, as more capable states are better equipped to react to violations of law and prevent them from occurring in the first place. However, a state capacity-centered explanation only takes us so far in explaining the observed outcomes. The three middle-income states have similar capacities and are each capable of at least allocating significant resources towards mitigating the challenge. However, there is a marked contrast between the different state responses, especially between Bolivia's inaction and the responses of its counterparts. Furthermore, state capacity does not explain why Colombia and Peru were able to react more comprehensively to the phenomenon after initial inaction. There is a political story behind these changes.

Secondly, it is sometimes argued that the responses were primarily ideological. In Bolivia, mining cooperativistas were crucial supporters of Evo Morales's leftist regime. From this perspective, government alignment with social movements would explain the cross-case variation. Right-wing governments, which have risen to power in Colombia and Peru in recent times, are said to lack this sympathy for small-scale miners and thus ultimately enforce regulations. Morales's relationship with cooperatives is certainly underpinned by ideological similarities and alliances built to win power. ${ }^{5}$ Nonetheless, the evidence suggests that any Bolivian government, regardless of its ideological inclinations, would have had to accommodate the interests of cooperativas. Over the past three decades, all Bolivian governments have accommodated the cooperatives' interests, including several right-wing governments. Considering the current right-wing coalition's accommodation of cooperatives, we believe that any Bolivian government would have pursued a strategy of forbearance during the gold rush. Ideological preferences may prompt some changes in the strategies pursued, but they do not determine fundamental state actions.

This article makes three contributions to the growing literature on the determinants of state action in developing countries. First, we highlight the relevance of studying institutional trajectories that strengthen or weaken social actors to fully elucidate what prompts different state responses to the challenges that emerge in the context of exogenous shocks such as the gold rush. Second, we highlight some empirical differences that allow us to distinguish between two different forms of state inaction (standoff and forbearance), which appear similar but are vastly different in origin. Third, and closely related to the second point, we show that standoff states can be more easily steered towards enforcement by different pressures (domestic or external) and that forbearance is rooted in strong political limits on state action. This difference is

\footnotetext{
${ }^{5}$ Carrillo et al. 2013.
} 
crucial not only for theorists attempting to understand formal institutional weakness in developing states but also for policymakers aiming to enforce regulations.

The article proceeds as follows. We start by discussing recent theories about determinants of state response, with an emphasis on works that focus on state inaction (standoff and forbearance). Second, we contextualize the relationships between artisanal miners and the state in the three countries pre-gold rush and document how states reacted (or did not react) to this challenge. Third, we analyze the aforementioned determinants of state response. We conclude by presenting some theoretical and practical implications.

\section{Theories of State Response}

A growing body of literature in comparative politics highlights the idea that emerging states' responses are determined not only by their capabilities but also by other social, economic, and political actors. As discussed in this state-in-society literature, states are frequently "pushed" into action by powerful actors that demand enforcement of regulations. ${ }^{6}$ These works observe that organized domestic actors (NGOs, unions, or business associations), pressure from international actors (international organizations, transnational NGOs, or other states), and political aversion to incurring serious political costs are determinants of state action. Furthermore, state capacity in certain policy areas often increases only in response to social and political pressures.

Other works focus on a less-studied phenomenon that also downplays a statecentered explanation, instead viewing government inaction as not just a consequence of state weakness, but also as a reflection of the decision by bureaucrats or politicians not to act. In this case, state actors have the capacity to do more but decide not to. This inaction can have various motivations, with very different consequences. Building on previous works, we divide state inaction into two categories: standoff and forbearance.

Writing about standoffish states, Slater and Kim have argued that states often prefer to "eschew the [...] routinized administration [...] of considerable portions of their subject population."7 According to the authors, Southeast Asian states refrained from directly governing areas occupied by violent groups despite having the capacity to do so, since inaction proved less costly. If states were standoffish when core interests were at stake, the authors expected such behavior to be even more common in response to far less important matters.

Thus, state actors may simply ignore challenges to their authority despite knowing that they exist and possessing the capacity to tackle them. Although Slater and Kim were less precise in this regard, the reasons behind such conscious inaction range from political disinterest to cost prevention. In other words, states may be aware of the issue but refrain from intervention due to the potential costs of action. To be sure, these costs are not insurmountable; otherwise, the phenomenon could be characterized as state weakness rather than standoff. The many cases of states eventually deploying resources

\footnotetext{
${ }^{6}$ Amengual and Dargent 2020; Amengual 2016; Holland 2016, Slater and Kim 2015; Migdal et al. 1994; O’Brien and Li 1999.

${ }^{7}$ Slater and Kim 2015, 37
} 
to enforce regulations provide clear evidence that initial inaction is not fundamentally determined by a lack of state capacity.

From this perspective, middle-income states are selective enforcers. Evolving issues or duties that may divert resources or lead to new problems can be strategically ignored. ${ }^{8}$ However, standoff can also carry high costs. The consequences of a particular phenomenon may not be initially evident, only to escalate to the point where the costs of toleration are prohibitive and thus motivate enforcement. At that point, the phenomenon may be more difficult to control.

That said, "not acting" can be associated with political gains rather than disinterest. Holland develops the concept of forbearance, defining it as "intentional and revocable government leniency toward violations of the law." cost prevention, governments may opt for inaction because of potential political gains. Holland illustrates these dynamics by analyzing the selective control of informal economies and land tenure in Latin America. In the latter case, not acting is a form of de facto redistribution that serves to build political linkages with citizens and social actors, leading to electoral gains. Thus, politicians - the central actors in Holland's theory-require powerful electoral incentives to move from forbearance to enforcement.

How does one distinguish empirically between standoff and forbearance if both strategies involve inaction of state actors due to some concern about preventing political costs? Holland has explained the theoretical difference between standoff and forbearance in terms of the revocability of forbearance, i.e., clear knowledge among nonregulated actors of the conscious but revocable decision not to enforce. " 10 "Revocable" does not imply that the state can effectively eliminate illegal activities, but that it can revoke its decision not to enforce regulations. States may fail to enforce effectively, but social actors know that their activities will become more costly if the forbearance pact is broken. Of course, there are also costs in confronting these actors - which surely made the political pact attractive in the first place - but the main motivation behind forbearance is political gain rather than merely cost aversion. Similarly, to the point about unsurmountable costs in the case of standoff, the phenomenon of a state refraining from enforcement mainly due to fear of social actors is better described as state weakness.

Awareness of a revocable pact prompts different interactions with social actors and different empirical observations for forbearance and standoff. In the case of forbearance, there is a recognized mutually beneficial (but often tacit) agreement in which social actors and the state are aware of the benefits of the agreement and the potential costs of breaking it. Political support from those who benefit from non-enforcement and from state actions to curb other agencies' timid regulatory options are good evidence of mutual awareness in forbearance pacts. In the case of standoff, there is no such tacit agreement and therefore no quid pro quo relations.

A second, albeit related, way to demonstrate a forbearance pact is to document state actions in other areas that promote or protect the unregulated activity. There may be forbearance in the enforcement of existing regulations but not in other activities that favor social actors benefited by the pact, such as policies that allow for the gains of the

\footnotetext{
${ }^{8}$ O’Brien and Li 1999

${ }^{9}$ Holland 2016, 13

${ }^{10}$ Holland 2016, 16-17
} 
tolerated informal activity to enter the formal economy. In cases of standoff, we should not expect state efforts elsewhere to promote unregulated activities or to erode other policies that affect them indirectly.

These characteristics show why it is easier to pass from standoff to enforcement than from forbearance to enforcement. In standoff, the state chooses inaction when the issue is not a priority or presents no political gains. It follows that when the state calculates that inaction becomes too costly or when other demands and pressures put the issue under the spotlight, enforcement will be chosen over standoff. Conversely, in forbearance, the state opts for inaction since enforcing regulation of certain issues could lead to loss of political support. Moving towards action would thus require a shock strong enough to mitigate this loss.

Our cases contribute to this literature by exploring the motivations behind observed state action and inaction. We highlight how the presence and nature of organized social actors determine state responses to the gold rush, illustrating conditions under which inaction becomes more costly and eventually moves standoffish states to enforcement (Colombia and Peru). In Peru, enforcement is motivated by a mix of domestic and international pressures in the form of corporate mining actors and NGOs. In Colombia, despite similar societal pressures, the type and depth of the measures ultimately adopted hinged on the state and social actors seeing gold as a pressing security issue. In turn, the Bolivian case illustrates how inaction can be deeply rooted in political incentives, limiting prospects for enforcement. In other words, action was deemed too costly for the state. In parallel, the Bolivian state benefited gold cooperatives through other policies such as taxes and state protection.

\section{One Gold Rush, Three Trajectories}

In this section, we first characterize small-scale gold mining in each country before moving on to the forms of state action and inaction vis-à-vis small-scale miners. In the next section, we explore the motivations behind the respective responses.

\section{Bolivia}

The most straightforward case in terms of state action against small-scale gold mining is Bolivia. There are no significant, observable changes before and during the period of the gold rush despite frequent environmental and legal violations. In this case, background conditions are most relevant for understanding the motivations behind the state's response to the gold rush.

To understand the importance of gold cooperatives during the resource boom, we need to consider the development of gold mining, mining unions, state-owned enterprises, and cooperatives in Bolivia in the mid-twentieth century. Gold mining has never been a major state enterprise. After the 1952 revolution, national mining enterprises concentrated on tin and zinc, while gold was left to cooperatives and some small- and medium-sized private ventures, ${ }^{11}$ but these were peripheral compared with their more prominent and influential zinc and tin counterparts.

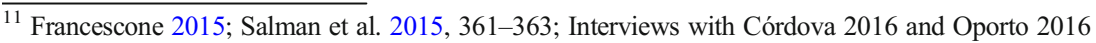


The Union Federation of Bolivian Mine Workers (FSTMB) was founded in 1944 and in 1952 became the backbone of the Bolivian Workers' Union (COB) through post-revolutionary reforms. Most miners worked for the Mining Corporation of Bolivia (COMIBOL), the state enterprise tasked with administering nationalized tin mines. In 1958, mining cooperatives were given legal recognition through the General Cooperatives Law (Law Decree 5053). ${ }^{12}$ Cooperatives are legally considered nonprofit associations with a democratic functioning, but they seldom fulfill this description, as many operate as profit-driven associations.

Twenty-five years later, the mining industry faced a crisis. In 1985, Bolivia introduced strong neoliberal reforms and dismantled COMIBOL. Approximately 23,000 miners were laid off and "relocated" to new positions. ${ }^{13}$ To calm social unrest, miners were permitted to form cooperatives and exploit state mines that had been abandoned or neared closure. ${ }^{14}$ Cooperative miners joined protests led by the Movement for Socialism (MAS), which eventually swept Evo Morales to power in 2005. Therefore, despite their comparative historical weakness, cooperative miners remained organized and gained political influence by joining active opposition to neoliberal reforms. Even if gold cooperatives had not been the biggest players, the commodity boom-which brought higher mineral prices and collaborative relations with the governmentstrengthened them.

Gold cooperatives operate in several parts of western Bolivia but are especially active along the Madre de Dios River in La Paz, Beni, and Pando, where they cause considerable environmental damage. ${ }^{15}$ Although no precise data is available on the current number of gold cooperatives in Bolivia, experts, cooperatives, and the state estimate the number rose from around 500 in 2007 to $1600-1700$ in 2014. In 2004, cooperatives comprised around 50,000 members, while by 2012 this number had increased to $150,000{ }^{16}$ Many of these new cooperatives engage in gold extraction ${ }^{17}$ and employ far more workers than the state and private enterprises put together. ${ }^{18}$

Despite the well-documented environmental damage of gold extraction, there have only been weak enforcement efforts, most of them swiftly curbed by other state actors. In general, the phenomenon is much less violent than in Colombia, although cooperatives sometimes clashed with the other organizations (e.g., traditional miners and peasant communities) that comprised MAS's social base, ${ }^{19}$ forcing the government to arbitrate.

Cooperatives were not mere subordinates to the government and kept their distance despite being allies, which sometimes generated conflict. For the most part, however, these disputes involved traditional, non-gold-producing cooperatives. The biggest conflicts involving gold cooperatives are with indigenous communities, with which they frequently negotiate for access to their lands. In summary, in Bolivia, the state has

\footnotetext{
${ }_{12}$ Rodríguez Ostria 2000; Michard 2008, 11-13; Espinoza 2010, 233-244; Francescone 2015, 747-749

13 Devisscher 2008:3; Toranzo 1989

${ }^{14}$ Anria 2013, 25-27

15 SPDA (Sociedad Peruana De Derecho Ambiental). 2015, 42-75; Córdova 2016

${ }^{16}$ Devisscher 2008; Cordova 2015, 64; Poveda 2015b, 58

${ }^{17}$ Salman et al. 2013, 22

${ }^{18}$ Salman et al. 2013, 22

${ }^{19}$ Anria 2013, 37; Francescone 2015; Salman et al. 2015, 363-364
} 
mostly remained inactive in enforcing regulations over gold miners despite extensive environmental damage and unregulated activities.

\section{Colombia}

Small-scale gold mining is a long-established activity in Colombia. It was one of the mining industry's fastest-growing subsectors during the first half of the twentieth century, partly due to laws that prioritized and encouraged it as a source of employment. In 1970, the state approved the first comprehensive legislation to formalize the sector, including small-scale mining. During the 1970s and 1980s, this legislation was supplemented by a series of additional decrees.

The most important legal change made before the gold rush was the 2001 Mining Code (Law 685), which aimed to unify and simplify the legal framework to attract private investment. Most significantly, the new code reduced state functions to regulation and policy formulation, shedding its previous corporate functions. ${ }^{20}$ The code also (at least declaratively) promoted associative, cooperative, and communitarian mining projects, ${ }^{21}$ although large-scale mining investment was prioritized. Furthermore, the code introduced mandatory environmental permits for mining and criminalized unlicensed exploration, making it difficult for artisanal miners to formalize their activities while benefiting mining corporations and other private actors. ${ }^{22}$

This investment-friendly code was part of President Alvaro Uribe's (2002-2010) broader security strategy linking private investment and territorial governance. After disengaging from state-run mining companies, the state used large-scale mining investment and title concession as a strategy to force out armed actors in certain areas at the expense of environmental damage to local indigenous and afro-Colombian communities. ${ }^{23}$ These changes contributed to the proliferation of private investment from 2003 onwards.

The Mining Code had several shortcomings relating to the regulation and formalization of artisanal mining (even if it did promote this subsector by facilitating access to titles and exploration), and it likely enhanced the growth of informality during the gold rush by complicating the formalization of traditional miners. The problems partly stemmed from the lack of information on informal mining - the last study predated the code by two decades. ${ }^{24}$ Overall, however, the reforms did not produce significant changes in the state's enforcement vis-à-vis gold extraction. In 2010, a mining census confirmed that the code had not led to fundamental changes, with only $15 \%$ of mining units operating with a mining title. ${ }^{25}$

What did change during the gold rush was that small-scale gold mining grew, spreading across several regions. In the Colombian case, gold quickly became another resource exploited by illegal groups. From the start, criminal gangs known as BACRIM, i.e., largely demobilized paramilitary groups, and drug traffickers were involved in gold exploitation. These groups had previously fought over other illegal

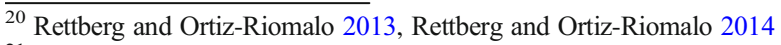

${ }^{21}$ Rettberg and Ortiz-Riomalo 2014

22 Vélez Torres 2014; Vélez-Torres 2016.

${ }^{23}$ Gutiérrez-Gómez 2017.

${ }^{24}$ Guiza 2010

${ }^{25}$ Rettberg and Ortiz-Riomalo 2013
} 
resources such as cocaine and opium as well as extortion opportunities in legal activities such as mining, banana production, and oil. ${ }^{26}$ However, they began to increasingly exploit various parts of the gold production chain in the territories they controlled while also moving to new areas containing the metal. As Echandía ${ }^{27}$ has demonstrated, by 2010, one fifth of revenues from illegal gold mining were held by the FARC, and over half of all gold-mining territories overlapped with areas where criminal gangs were present.

Violence has had a clear effect on internal migration during Colombia's gold rush. These violent actors preyed upon artisanal miners, sometimes claiming and obtaining mining titles for lands already exploited by these local communities, which were now considered illegal actors. ${ }^{28}$ While the gold-producing regions initially experienced the traditional net immigration ${ }^{29}$ seen in the other countries, this gave way to emigration. ${ }^{30}$ As Ibañez and Lavarde ${ }^{31}$ have documented, the average number of forced displacements is considerably higher in gold-producing districts than elsewhere in Colombia. The involvement of armed actors is also evidenced by the increase in gold production in departments where armed groups predominated such as Chocó, where production exceeded that of traditional mining departments like Bolivar. ${ }^{32}$ Thus, the gold rush fueled violent challengers and reinvigorated the armed conflict, ${ }^{33}$ particularly in areas with gold deposits. ${ }^{34}$

Although the impact of gold production on Colombia's conflict and the environment was well documented, the state's initial response was to ignore the issue and continue with weak enforcement of previous formalization measures. The state continued to focus its strategy on attracting private mining corporations; much less attention was given to the formalization of artisanal miners already working on these territories. When formalization of small miners did happen, it frequently favored new-and illegal - actors that preyed on traditional communities that could not meet the requirements for formalization. ${ }^{35}$ In other words, during the early years of the boom, the state was largely standoffish to the growth of small-scale informal gold mining.

A turn towards enforcement occurred from 2009 to 2011, when the state introduced significant reforms - many of which focused on security - to tackle the phenomenon. In 2009, Law 133 established that the Colombian police force would accompany environmental authorities on visits to areas with security and public order concerns and called for coordination between the police and the army to help identify illegal mining activities. This shift was also apparent in the government's development plans, which presented the main policy goals and proposals. The 2010-2014 National Development Plan of Juan Manuel Santos' government (2010-2018) prohibited the use of heavy machinery in mining activities without titles. Later, the 2014-2018

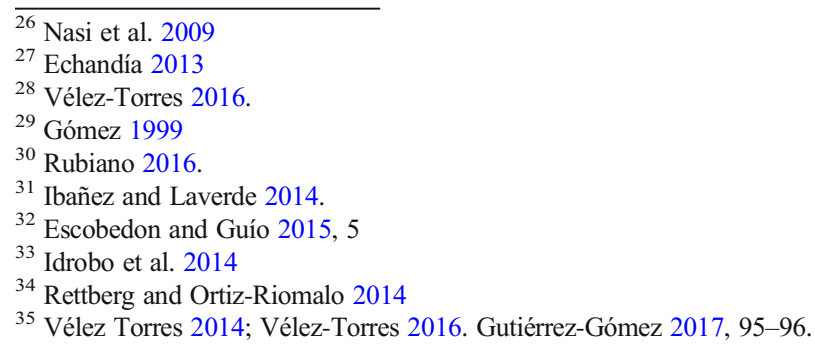


National Development Plan compelled the state to deal with the environmental damage caused by small-scale gold mining.

Law 1382, enacted in 2010, established a period of 2 years for traditional miners' groups and associations to formalize and meet the requirements for formal mining concessions. In 2011, the government created the National Mining Agency (ANM) to regulate and process mining titles and applications. Later that year, the government proposed a Comprehensive Security and Defense Policy for Prosperity with the declared aim of promoting security and development through private investment. Even stronger political actions were taken after January 2012, when the Santos administration declared war on illegal mining due to its linkages with armed actors. In October of 2012, Decree 2235 stipulated that those engaged in mining activities without a mining title or an environmental license would have their heavy machinery destroyed. ${ }^{36}$

This turn towards stronger political action provoked a national miner strike in 2012. Their main grievance was Decree 2235, which provided for the destruction of machinery used in non-regulated mining activities. A post-strike agreement required the Ministry of Defense to prove the link between the machinery and the illegal activities before destroying it.

Otherwise, the state's efforts proved difficult to implement partly due to the armed actors involved. Law 1381, which allowed informal miners undergoing formalization to continue operating, was repealed after many armed groups posed as informal miners or forcibly occupied concessions registered by informal miners. In addition, a variety of commentators pointed to the shortcomings of a securitization and formalization strategy that was too demanding for artisanal miners and thus ended up favoring other actors such as private corporations or illegal groups involved in gold extraction. ${ }^{37}$ In sum, the gold rush in Colombia went from being a non-priority for the state, addressed through existing albeit flawed laws and regulations, to an emergency.

\section{Peru}

For much of the twentieth century, Peru's small-scale gold mining industry was comparable to that of Bolivia and Colombia. Between 1950 and 1980, the state promoted artisanal and small-scale mining. Since most gold deposits could be found in or around the Amazon, the promotion of small-scale mining conformed to broader state development of the rainforest. In 1972, the state declared a monopoly over gold commercialization through the Mining Bank, which became an important agency for the promotion of small-scale mining. As well as buying gold, this agency registered miners by conceding plots, ${ }^{38}$ imposed conditions on exploitation, and mediated conflicts between miners and indigenous communities. ${ }^{39}$ However, the state did little else to formalize small-scale gold mining.

By the 1980s, informal gold mining had become a serious problem, and the unsuccessful efforts of the Mining Bank and other agencies prompted the miners to attempt self-organization. Grouped into departmental associations coordinated on a

\footnotetext{
$\overline{36}$ This decree regulated Decision 774 "Política Andina de Lucha contra la Minería Ilegal" (7-30-2012) of the Andean Community of Nations (ACN).

${ }^{37}$ Vélez Torres 2014; Vélez-Torres 2016.

${ }^{38}$ Romero et al. 2005

${ }^{39}$ Valencia 2014
} 
national scale, miners acted to address informality and negotiate more comprehensive regulation with the state. ${ }^{40}$ Various phenomena in the late 1980 s and early $1990 \mathrm{~s}$ weakened these attempts at self-organization. A severe economic crisis hit Peru in the 1980s, weakening both unions and grassroots associations. Internal violence unleashed by Sendero Luminoso killed thousands and debilitated social networks across the country. Finally, market reforms in the 1990s, including privatization of state mines, disempowered small miners' associations. At the same time, the reformers dismantled the Peruvian developmental state, including the Mining Bank. The state did little to promote artisanal mining, focusing instead on large-scale interests. ${ }^{41}$ Thus, until the boom, small-scale gold mining remained a minor economic activity confined to a few Andean departments and the Amazonian department of Madre de Dios. ${ }^{42}$

This situation began to change when, during the boom, thousands moved to Madre de Dios, Puno, and other Andean departments and the northern departments of La Libertad and Piura to work as miners. ${ }^{43}$ This migration created a grassroots base composed mainly of artisanal workers. Damonte ${ }^{44}$ estimated their numbers at 53,600 in 2009, but the upward trend has continued since then; the population of Madre de Dios town grew by $2.5 \%$ per year between 2005 and $2015 .{ }^{45}$ Moreover, the Regional Office of Energy and Mining in Puno calculated that the small gold town of La Rinconada $^{46}$ soared from a population of approximately 5000 in 2007 to 65,000 70,000 in 2015 .

The state's response varied over time. During the early years of the rush, it largely ignored the phenomenon. ${ }^{47}$ From 2002 to 2009, there were a few attempts at formalization but no clear direction. Moreover, in 2002, the state and the newly created regional governments clashed over distributions of responsibilities. The initial efforts faced several obstacles that snowballed as the boom progressed, particularly overlapping agricultural, forestry, and mining concessions, which made it difficult for miners to begin the formalization process.

An early state response to the issue occurred in 2010 via the Emergency Decree 0122010, which focused on Madre de Dios. This resulted in some police and military actions in that department, but deficient coordination and limited resources meant that they were more symbolic than effective. ${ }^{48}$ Indeed, during these early stages, the state was hindered by a lack of adequate legislation, specialized bureaucracy, and resources. $^{49}$

It was not until Ollanta Humala's presidency (2011-2016) that the state began to change course towards a more emphatic stance against informal gold mining, even though Humala had campaigned alongside miners' associations. His government launched a formalization plan and allocated more funds to the agencies tasked with

\footnotetext{
${ }^{40}$ Romero et al. 2005

${ }^{41}$ Romero et al. 2005

${ }^{42}$ Kuramoto 2001

43 Alvarado 2014; Damonte et al. 2013; Pachas 2013

${ }^{44}$ Damonte 2013

45 BCR 2015, 2

${ }^{46}$ Interview with Angel Neira

${ }^{47}$ Dargent and Urteaga 2017

${ }^{48}$ Interview with Abanto 2014

${ }^{49}$ Defensoría del Pueblo 2014; Interview with Herrera 2014; Interview with Raez 2014
} 
controlling the issue, ${ }^{50}$ while introducing a distinction between illegal and informal mining. Illegal mining, interpreted as all mining carried out in protected areas (e.g., natural reserves), cannot be formalized and is prosecutable. Conversely, informal mining, i.e., mining conducted without the proper permits, can potentially be formalized. Although informal mining is also effectively illegal since it breaches formal requirements, this distinction allowed for a "divide and conquer" strategy aimed at rapprochement with informal miners and punishment of illegal ones.

Although these laws and formalization attempts were unprecedentedly comprehensive, they still achieved limited results largely due to serious problems in certifying and regulating land titles. ${ }^{51}$ As our fieldwork in Madre de Dios shows, overlapping land titles — which are subject to competing logging, farming, and mining titles - frequently made formalization even more difficult. Moreover, eradication is costly and difficult to sustain over time, and banned miners quickly returned to their activities. From 2016 onwards, this enforcement drive waned somewhat after Pedro Pablo Kuczynski's government (2016-2018) passed decrees that loosened criminalization of informal mining ${ }^{52}$ and generally deprioritized the issue. In 2019, Martin Vizcarra's administration (2019-) launched a fresh wave of regulatory efforts in Madre de Dios, establishing a more permanent military presence in the region. It remains to be seen whether this will be extended to other gold-producing regions. Thus, regulation and formalization continue but with fluctuations.

\section{Determinants of State Response}

To explain the varying state responses, we need to revisit the countries' political and institutional trajectories before gold prices increased and how they shaped the nature of the social actors. In Bolivia's case, the trajectories allowed influential social and political actors to gain resources from gold extraction, limiting the state's options and precipitating forbearance. In Colombia and Peru, there were no such powerful actors around gold mining, so in both cases the state was able to opt for standoff by ignoring the issue either because the state considered it unimportant or less of a priority than other issues. However, violent actors made standoff far more costly in Colombia, which explains the state's quicker and more comprehensive shift towards enforcement. In Peru, international condemnation of Amazonian depredation and the local demands of large-scale mining enterprises mainly explain state action.

\section{Bolivia}

Compared with the other two countries, Bolivia's response of inaction was far more stable. Political considerations motivated this inaction, as state elites believed that enforcement would be too politically costly. Indeed, some state actions facilitated small-scale gold extraction, and there have been only a few timid and limited enforcement efforts.

\footnotetext{
${ }^{50}$ OEFA 2013

${ }^{51}$ Interview with Abanto; Defensoría del Pueblo 2014

52 Dec. Leg 1351 of January 7, 2017.
} 
As discussed in the previous section, mining cooperatives amassed considerable political power over time. Gold extractors, from old cooperatives to new miners, found the cooperative structure perfect for exploitation. Emerging gold cooperatives quickly became embroiled in the relationship between MAS and traditional cooperatives. As a result, these organizations channeled the gold rush, becoming a strong pressure group with an agenda separate from that of pre-existing cooperatives. Thus, the gold rush was primarily a political phenomenon in Bolivia.

The idea that prolonged state inaction in Bolivia reflects a conscious political calculus of tacit approval rather than state weakness is evidenced by the multiple linkages between MAS and the cooperatives, constituting an informal pact of non-enforcement. One analyst of Bolivian mining politics thinks that cooperatives cogoverned alongside Morales, an observation in line with many studies documenting MAS's social bases. ${ }^{53}$ Moreover, the cooperatives are well represented in government: around a dozen congressmen act on behalf of mining cooperatives, actors with close links to cooperativessometimes even former cooperative leaders - have served as vice-ministers of mining development and cooperatives, cooperatives occupy a seat in COMIBOL, and cooperative members run for local elections on MAS parliamentary lists.

However, cooperatives-contrary to expectations in a classic corporatist agreement - do not actually receive many state payouts. Although the government reduced taxes for cooperatives (2.5\% under the new mining law) and gave them machinery and loans to expand their operations, ${ }^{54}$ the basic quid pro quo under these pacts is forbearance: the cooperatives are allowed to operate without regulations being enforced. As Salman et al. have noted, "they are privileged, and nobody dares to touch them." 55 An independent report on gold mining and cooperatives in Bolivia highlights how the lack of enforcement of criminal, environmental, and tax regulations assures cooperatives of considerable gains. While the state supports gold miners with "mining rights where they ask for them, and also multi-million credits and lower taxes," the "lack of enforcement is the biggest incentive," 56 enabling vast profits through exploitation of areas lacking formally recognized rights.

Additional evidence of forbearance can be found in the government's incentivization and facilitation of gold extraction and even the frustration of its own timid enforcement efforts. According to Antonio Ganderillas, an expert in informal gold mining, this system of "undoing with one hand what one does with the other" proves that the government has no intention of enforcing the law. Gold extraction activities that do not comply with regulations are expressly prohibited and formally punishable, but loopholes effectively legalize these activities. The 2014 Mining Law forbids illegal mining yet authorizes cooperatives to operate while they undergo formalization. For Ganderillas, the mining law ultimately allows cooperatives to function undisturbed. ${ }^{57}$

In addition, the government has tolerated tax evasion. Cooperatives pay royalties at lower rates than mining companies, but many still fail to do so or are allowed to pass off their gold as lower quality to lower their tax burden. ${ }^{58}$ This lax application,

\footnotetext{
$\overline{53}$ Anria 2013; Salman et al. 2015, 363; Salman et al. 2013:22; Interview with Oporto 2016

54 SPDA (Sociedad Peruana De Derecho Ambiental). 2015: 30-32

55 Salman et al. 2013, 23.

${ }^{56}$ Gandarillas et al. 2013:3, translated by authors

${ }^{57}$ Interview with Ganderillas 2016

${ }^{58}$ SPDA (Sociedad Peruana De Derecho Ambiental). 2015: 34-39; Cordova 2015
} 
Ganderillas has argued, occurs despite tax authorities firmly enforcing collection in recent years. ${ }^{59}$

As an example of government actors limiting coercive actions against informal mining, Héctor Córdova recalled that in 2010, when he was Vice Minister of Mining (Ministry of Mining and Metallurgy), five of the state's operations to curb tax evasion by small-scale miners in frontier areas failed when the Vice Ministry for Cooperatives (under the same ministry) identified the organizations involved as cooperatives. ${ }^{60}$ All of the evidence points to a forbearance pact between the government and cooperatives in Bolivia.

\section{Colombia}

As previously seen, Colombia's gold rush was shaped by violent actors active since the second half of the twentieth century. This made gold extraction a highly violent and risky activity, controlled in many areas by criminal organizations that used their resources and accumulated know-how to extract and export gold. ${ }^{61}$ Furthermore, when formalization did happen, it frequently benefited illegal actors who used regulations to displace artisanal miners. ${ }^{62}$ However, even under these conditions and high political costs, the state's initial approach was standoff.

Eventually, the government acknowledged the problem and was compelled to act. As in other countries, domestic and international pressures pushed the issue onto the public agenda. The alarm was largely sounded by domestic and international environmental and human rights organizations. As well as highlighting internationally prevalent concerns related to the environment, exploitation, and informality, their analyses also stressed the effects of gold mining on Colombia's ongoing armed conflict. ${ }^{63} \mathrm{~A}$ 2011 report from Fundación Ideas para la Paz, for example, alerted that there were armed groups in already more than half of the gold-producing municipalities. ${ }^{64}$

As well as international and domestic pressures, Colombia's eventual pivot to enforcement addressed internal state concerns, particularly with regard to security agencies, which explains the prominence of security in the policies adopted and resources mobilized. Consequently, state actors eventually designed and implemented a more comprehensive and vigorous response to the gold challenge, with a stronger emphasis on security than in Peru.

As evidence of these internal state concerns, the reforms were drafted and proposed as part of an ongoing security strategy that led to institutional adjustments within the state. Several state reports analyzed the issue and made policy proposals. ${ }^{65}$ In 2012 , the Unit of Environmental Crimes was established within the National Attorney General's Office. From 2013 to 2014, the Attorney's Office denounced money laundering activities linked with gold mining. In 2014, the state also implemented the National Unit against Illegal Mining and Terrorism under the Uniformed Police and Rural

\footnotetext{
$\overline{59}$ Interview with Ganderillas 2016

${ }^{60}$ Interview with Cordova 2016

${ }^{61}$ Massé and Camargo 2012

${ }^{62}$ Vélez Torres 2014; Vélez-Torres 2016.

${ }^{63}$ Vicente et al. 2011; Ruíz 2011.

${ }^{64}$ Fundación Ideas para la Paz 2011.

${ }^{65}$ Comptroller General of the Republic of Colombia 2011; Defensoría del Pueblo 2010; Guiza 2010;
} 
Security Directorate of the police force to study the link between gold and criminal organizations. In 2015, a brigade was created within the army to combat illegal mining.

Moreover, although there is scant evidence of private mining actors exercising pressure on the state to regulate informal mining during the early years of the gold boom, these demands eventually grew. The new Colombian Mining Association (ACM), founded in 2014, actively demanded more regulation through press releases and statements and also pointed to security concerns. ${ }^{66}$ In 2015, ACM president Santiago Angel denounced illegal mining and presented it as a problem for the operations of formal miners. In 2016, he stated that $88 \%$ of the country's gold production was illegal. A year later, the ACM joined the call made by the General Comptroller of Colombia, Eduardo Maya, to counter illegal mining in the country. According to Angel, "It is urgent that the necessary measures be taken to combat those who illegally extract these resources without having the necessary permits and licenses, intimidating communities and stealing important economic resources from all Colombians[...]. ${ }^{, 67}$ As we will also see in the Peruvian case, these statements put corporate and informal mining into opposition with the intention of highlighting the benefits of the former (and minimizing its own social impacts).

The Colombian case shows the importance of violence in explaining the state's turn to a more comprehensive and security-centered strategy. Standoff proved a costly decision in the medium term, and it is somewhat surprising that the state was so slow to act in the beginning. Ultimately, however, this proves Slater and Kim's point about standoff being a particularly common state approach in developing states.

\section{Peru}

In Peru, the lack of organized actors around small gold mining - whether political or violent - explains why the state has had more leeway in choosing different ways of responding to the phenomenon and why its standoff lasted longer than Colombia's. As previously mentioned, informal mining in Peru is largely fragmented. Mining unions (artisanal or otherwise) were by no means as extensive or strong as in Bolivia, so there were no similar patterns of organization. Furthermore, the political involvement of gold extractors was mostly confined to the local level. The emergence of gold as an essential component of some communities' economies and the influx of miners assured local pro-mining candidates of a high number of votes. Mayoral and even regional gubernatorial candidates have run - and frequently won - with the backing of gold miners. However, while some legislators in Congress have links to gold extraction, these relationships are present to a much lesser degree than in Bolivia.

As noted earlier, this lack of organization can be explained by various phenomena that unfolded in the late 1980s and early 1990s such as the economic crisis, the rise of Sendero Luminoso, the dismantling of the developmental state, and market reforms. All of these factors contributed to the weakening of small miners' organizations. Moreover, the near-total defeat of Sendero Luminoso in the 1990s rid the country of its major violent agents. Thus, in the absence of political actors who might have made

\footnotetext{
${ }^{66}$ País Minero "Con Nuevo Sistema Buscan Atajar el Comercio Ilegal de Oro", 23/01/2015; Portafolio "El 88\% de la producción de Oro en Colombia es ilegal: ACM". 02/08/2016.

${ }^{67}$ La República “Asociados a AMC piden ley para combatir la minería ilegal. 23/10/2017.
} 
forbearance more attractive or violent ones who may have demanded quick and more thorough enforcement, Peru was less constrained in determining a comprehensive state response. Standoff seemed to be a more permanent option.

Nonetheless, the state's standoffish attitude gradually gave way to a more comprehensive response due to external and domestic pressures. These included (i) the need to guarantee environmental commitments established in the free-trade agreement with the USA, prompting the creation of a Ministry of the Environment in 2009 whose initial actions were against gold mining in the Amazon basin ${ }^{68}$; (ii) the growing pressure associated with the international campaign by transnational environmental networks and their domestic allies against pollution related to gold extraction ${ }^{69}$; and (iii) starting in 2009-2010, formal and powerful mining companies calling upon the state through press releases and declarations to respond to the challenge. ${ }^{70}$ During the boom years, the expansion of mining activities catalyzed social conflicts and formal mining enterprises faced repeated allegations of causing environmental damage. Their resulting negative image spurred these enterprises to launch a public campaign between 2010 and 2011 to show that they did in fact comply with environmental regulations and that the "real" polluters were informal mining groups. Various press releases attested to the deep involvement of the Confederation of Private Peruvian Enterprises (CONFIEP) and the National Mining and Petroleum Association (SNMP) ${ }^{71}$ in ongoing efforts to induce enforcement.

Other sources point to growing alarm among external actors regarding security issues. In an interview for this study, Salomón Lerner, Humala's first Head of Cabinet, admitted that it was not clear what had changed the president's mind regarding smallscale mining, but he recalled that Humala had started to worry about the issue due to links between gold mining and transnational criminality.

What seems clear is that these cumulative pressures moved the state to enforcement. Nonetheless, as recent events demonstrate, the scope for reverting from enforcement to standoff was greater than in Colombia. The fact that after Humala's presidency some politicians - most notably Keiko Fujimori, who promised miners greater leniency during her campaign, and Kuczynski, who showed a more tolerant stance towards informal mining during his government-shows that the state has more leeway to change its strategy and revert to standoff.

\section{Conclusion}

The study of the gold rush in these three Andean countries provides us with some important theoretical insights as well as some practical lessons for policymakers. First,

\footnotetext{
${ }^{68}$ Ruíz 2011

${ }^{69}$ Mosquera 2009; Swenson et al. 2011; Gardner 2012

${ }^{70}$ Interviews with Abanto [2014] and Galliani [2014]

${ }^{71}$ SNMP: Minería ilegal en Perú mueve más de US\$ 900 millones que no pagan impuestos y regalías (February 22, 2011); CONFIEP: Narcotráfico “invierte" US\$ 500 millones al año en minería ilegal (February 14, 2012); SNMPE: Destaca voluntad política del gobierno para erradicar la minería ilegal en Perú (February 20, 2012); SNMPE: Gobierno no se enfrenta a minería de subsistencia sino a mafias que financian extracción ilegal de minerales (March 14, 2012); SNMPE: ni un paso atrás en la lucha contra la minería ilegal (May 16, 2012); among others.
} 
the findings highlight the importance of social actors for understanding the differential impacts of external factors in domestic politics and how these actors accordingly shape state responses. This contextual knowledge is crucial to fully understand how states react differently to challenges prompted by the similar exogenous shocks.

Secondly, the cases highlight why external and domestic pressures for enforcement are more effective in states that adopt standoffish approaches than in states that prefer forbearance. Standoff is cost preventive at best, while the benefits of forbearance must first be surpassed to prompt the state into action. Moreover, states that forbear regulations tend to adopt a series of formal and informal institutions to provide incentives for unregulated actors, which also constitute barriers to enforcement. These barriers may become more formidable over time as these policy incentives build up social power.

Finally, and related to the previous point, these cases offer some practical lessons for state reformers concerned about the costs of informal gold mining. Actors interested in moving forward with regulations are advised to explore the reasons behind state inaction. If forbearance is at the heart of the decision, it will be more difficult to lobby the state for change. On the contrary, standoff seems to be a more flexible position from which to motivate states to act.

Open Access This article is licensed under a Creative Commons Attribution 4.0 International License, which permits use, sharing, adaptation, distribution and reproduction in any medium or format, as long as you give appropriate credit to the original author(s) and the source, provide a link to the Creative Commons licence, and indicate if changes were made. The images or other third party material in this article are included in the article's Creative Commons licence, unless indicated otherwise in a credit line to the material. If material is not included in the article's Creative Commons licence and your intended use is not permitted by statutory regulation or exceeds the permitted use, you will need to obtain permission directly from the copyright holder. To view a copy of this licence, visit http://creativecommons.org/licenses/by/4.0/.

\section{References}

Alvarado BL. Impactos y lecciones aprendidas de la minería ilegal e informal en Madre de Dios. Econ Soc. 2014;84(1):56-63.

Amazon Conservation Association. (2014). Fact Sheet: Illegal gold mining in Madre de Dios, Peru [Online]. Available at: http://www.amazonconservation.org/pdf/gold_mining_fact_sheet.pdf [Accessed 25 February 2015].

Amengual M. 2016. Politicized enforcement in Argentina. Labor and Environmental Regulation. Cambridge University Press.

Amengual M and Dargent E. 2020. The social determinants of enforcement. In Brinks D, Steve Levitsky and María Victoria Murillo eds. The Politics of Institutional Weakness, New York: Cambridge University Press, 161-182.

Anria S. Social movements, party organization, and populism: insights from the Bolivian MAS. Latin Am Polit Soc. 2013;55(3):19-45.

Ashe K. Elevated mercury concentrations in humans of Madre de Dios, Peru. PLoS One. 2012;7(3):1-6.

BCR (BANCO CENTRAL DE RESERVA DEL PERU). 2015. Caracterizacion del departanento de Madre de Dios. Available in: http:/www.bcrp.gob.pe/docs/Sucursales/Cusco/madre-de-dios-caracterizacion.pdf

Carrillo F; Salman T \& Soruco C. 2013. Cooperativas de minería de pequeña escala en Bolivia: De salvavidas de los pobres a maquinaria de manipulación política. Letras Verdes, Revista Latinoamericana de Estudios Socioambientales.

Comptroller General of the Republic of Colombia. 2011. La explotación ilícita de recursos minerales en Colombia, Casos del valle del Cauca (Río Dagua) y Chocó (Río San Juan), Efectos Sociales y Ambientales. 
Cordova H. Oro Boliviano? In: CEDLA, editor. La Economía del Oro: Ensayos sobre la Explotación en Sudamérica. La Paz: CEDLA; 2015. p. 61-75.

Cremers L, Kolen J, de Theije M. Small-scale gold mining in the Amazon: the cases of Bolivia, Brazil, Colombia, Peru and Suriname. Amsterdam: CEDLA; 2013. p. 68-84.

Damonte G. 2013. Formalizing the unknown. The stalemate over formalizing small-scale mining in Madre de Dios The Broker [Online] Available at: http:/www.thebrokeronline.eu/Articles/Formalizing-theunknown [Accessed 23 February 2015].

Damonte G, De Mesquita B, Mourik P, Hugo V, Chávez AM. Small-scale gold mining and social and environmental conflict in the Peruvian Amazon. In: Cremers L, Kolen J, de Theije M, editors. Small-scale gold mining in the Amazon: the cases of Bolivia, Brazil, Colombia, Peru and Suriname. Amsterdam: CEDLA; 2013. p. 68-84.

Dargent E, Urteaga M. Adaptación Estatal por Presiones Externas: Los Determinantes de la Respuesta Estatal al Boom del Oro en el Perú (2004-2015). Revista de Ciencia Política. 2017;36(3):655-77.

Defensoría Del Pueblo. Gestión del Estado frente de la minería informal e ilegal en el Perú. Report $N^{\circ} 167$. Lima: Defensoría del Pueblo; 2014.

del Pueblo D. La minería de hecho en Colombia. Bogotá: Defensoría del Pueblo; 2010.

Devisscher T. 2008. Cinco Siglos de Acumulación de Costos Socio-Ambientales: La Actividad Minera en Bolivia. Documento de Trabajo. La Paz: PNUD.

Eaton K. The state of the state in Latin America: challenges, challengers, responses, and deficits. Revista de Ciencia Politica. 2012;32(3):643-57.

Echandía, Claudia. (2013). Narcotráfico: Génesis de los paramilitares y herencia de bandas criminales. Fundación ideas para la Paz Serie Informes No 19.

Escobedon R, and Nadia Guío.2015. Oro, crimen organizado y guerrillas en Quibdó. [online]. Available at: http://www.ideaspaz. Org/publications/posts/1154.

Espinoza J. Minería Boliviana: Su realidad. La Paz: Plural; 2010.

Francescone K. Cooperative miners and the politics of abandonment. Ext Ind Soc. 2015;2(4):746-55.

Fundación Ideas para la Paz. Boletín Temático No. 2: Minería y Derechos Humanos. Bogotá: FIP; 2011.

Gandarillas, Marco, Georgina Jiménez and Jorge Campanini. 2013."Arcopongo: La actual política minera alienta los conflictos mineros". Dossier CEDIP. Cochabamba: CEDIP.

Gardner, Elie. 2012. “. Nature 486: 306-307 [online]Peru battles the golden curse of Madre de Dios". Nature 486: 306-307 [online]. Available at: http://www.nature.com/news/peru-battles-the-golden-curse-ofmadre-de-dios-1.10857 [Accessed 23 February 2015].

Gómez A. Estructuración socio-espacial de la Amazonía colombiana, siglos XIX y XX. In: Cubides F, Domínguez C, editors. Desplazados, migraciones internas y estructuraciones territoriales. Bogotá: Centro de Estudios Sociales; 1999.

Guiza L. La Minerìa De Hecho En Colombia. Bogota: Defensoría del Pueblo; 2010. http:/www.defensoria. org.co/red/anexos/publicaciones/mineriaColombia.pdf

Gutiérrez-Gómez L (2017). "Mining in Colombia: tracing the harm of neoliberal policies and practices". Rodríguez Goyes, D., Mol, H., Brisman, A., South, N. (Eds.). Environmental Crime in Latin America: The Theft of Nature and the Poisoning of the Land, pp. 85-113.

Holland A. Forbearance. Am Polit Sci Rev. 2016;110(2):232-46.

Ibañez AM, Laverde M. Los municipios mineros en Colombia: características e impacto sobre el desarrollo. In: Benavides J, editor. Insumos para el desarrollo del Plan Nacional de Ordenamiento Minero. Bogotá: Ediciones Uniandes; 2014.

Idrobo N, Mejía D, Ortiz-Riomalo JF, Rettberg A. Coca y oro. Explorando y analizando la relación entre el cultivo de coca y la producción de oro en Colombia. Mimeo. Bogotá: CESED, Universidad de los Andes. 2014.

Kuramoto J. 2001."La minería artesanal e informal en el Perú”. Mining, minerals and development. N.81, septiembre 2001.

Massé F, and Camargo J. 2012. Actores Ilegales y Sector Extractivo en Colombia. V informe del Observatorio Internacional de Colombia (Online). http://www.askonline.ch/fileadmin/user_upload/documents/Thema Wirtschaft_und_Menschenrechte/Bergbau_Rohstoff/Gold/Actores_armados_ilegales_sector_extractivo. pdf. Accessed 5 Jan 2016.

Michard J. Cooperativas Mineras en Bolivia. Cochabamba: DIDAB; 2008.

Migdal JS, Atul K, Shue V. State power and social forces: struggles and accommodation. Cambridge: Cambridge University Press; 1994.

Mosquera C. Estudio diagnóstico de la actividad minera artesanal en Madre de Dios. Lima: Fundación Conservación Internacional; 2009. 
Nasi C, Leiteritz R, Rettberg A. Para desvincular los recursos naturales del conflicto armado en Colombia. Colombia Internacional. 2009;70(July to December 2009):215-29.

O’Brien K, Li L. Selective Policy Implementation in Rural China. Comparative Politics. 1999; 31(2):167-86.

OEFA (Organismo De Evaluación Y Fiscalización Ambiental). Fiscalización ambiental a la pequeña minería y minería artesanal. Lima: OEFA; 2013.

Pachas VH. Conflictos sociales en Madre de Dios: El caso de la minería en pequeña escala de oro y la ilegalidad. Lima: CEAS; 2013.

Poveda P. El Oro en la Economía Internacional. In: Poveda P, Nogales N, Calla R, editors. El oro en Bolivia: Mercado, producción y medio ambiente. La Paz: CEDLA; 2015a.

Poveda P. (2015b). Contexto Internacional de la Producción del Oro. In CEDLA. ed. La Economía del Oro: Ensayos sobre la Explotación en Sudamérica. La Paz: CEDLA: 1-59.

Rettberg A, Ortiz-Riomalo J. Golden Opportunity, or a New Twist on the Resource-Conflict Relationship: Links between the Drug Trade and Illegal Gold Mining in Colombia. Bogotá: Mimeo - CESED, Universidad de los Andes; 2013.

Rettberg A and Ortiz-Riomalo J. 2014. Conflicto Dorado: Explorando La Relación Entre Minería De Oro, Conflicto Armado y Criminalidad En Colombia (Golden Conflict: Exploring the Relationship Between Gold Mining, Armed Conflict, and Criminality in Colombia) (April 1, 2014). Available at SSRN: https://ssrn.com/abstract=2418883 or https://doi.org/10.2139/ssrn.2418883

Rodríguez Ostria, G. 2000. "De trabajadores a individuos. El sindicalismo minero en perspectiva histórica". In Fundemos and Fundación Hans Seitel, eds. El Sindicalismo en Bolivia. La Paz: Hans Seidel/Fundemos 35-74.

Romero MK, Pachas VH, Zambrano G, Guarniz Y. Formalización de la Minería en Pequeña Escala en América Latina y el Caribe: un análisis de experiencias en el Perú. Lima: CooperAcción, Acción Solidaria para el Desarrollo; 2005.

Rubiano N 2016. Habitaciones en disputa. El impacto de la minería de oro sobre el desplazamiento forzado en Colombia: 2001-2015. Undergraduate thesis. Bogotá: Universidad de los Andes.

Ruíz M. 2011. Análisis del proceso de implementación del capítulo ambiental del acuerdo de promoción comercial entre Estados Unidos y Perú: La situación Peruana. Resumen de Políticas. Lima: BID.

Salman T, Carrillo F and Soruco C. 2013. "Cooperative Orgaization and balsa Mining in Bolivia". In Cremers, Leontien, Judith Kolen and Marjo de Theije, eds. Small-scale gold mining in the Amazon: the cases of Bolivia, Brazil, Colombia, Peru and Suriname, Amsterdam: CEDLA: 68-84.

Salman T, Carrillo F, Soruco C. Small scale mining cooperatives and the state in Bolivia: their stories, memories, and negotiation strategies. Ext Ind Soc. 2015;38(2):360-7.

Slater D, Kim D. Standoffish states: nonliterate leviathans in Southeast Asia. Trans-Regional Natl Stud Southeast Asia. 2015;3(1):1-20. https://doi.org/10.1017/trn.2014.14.

SPDA (Sociedad Peruana De Derecho Ambiental). Las rutas del oro ilegal: Estudios de caso en cinco países amazónicos. Lima: SPDA; 2015.

Swenson J, Carter CE, Domec J-C. Gold mining in the Peruvian Amazon: global prices, deforestation, and mercury imports. PLoS One. 2011;6(4):1-7. https://doi.org/10.1371/journal.pone.0018875.

Tansey O. Process tracing and elite interviewing: a case for non-probability sampling. PS: Political Science \& Politics. 2007;40(04):765-72.

Toranzo C. Desproletarización e informalización de la sociedad boliviana. Investig Econ. 1989;48(julyseptermber):197-223.

Valencia L. Madre de dios: ¿Podemos evitar la tragedia? Políticas de ordenamiento de la minería aurífera. Lima: SPDA; 2014.

Vélez Torres I. Dimensiones Del Extractivismo Minero en Colombia. Análisis De Las Racionalidades De Gobierno Durante La última Década. Análisis Político. 2014;27(82):45-57.

Vélez-Torres I. Disputes over gold Mining and dispossession of local Afrodescendant communities from the Alto Cauca, Colombia. Third World Thematics. 2016;1(2):235-48.

Vicente et al. 2011. Mining in Colombia: At what cost? PBI Colombia 18. CÓDICE Editorial. In: https://www.peacebrigades.org/fileadmin/user_files/projects/colombia/files/colomPBIa/111203_mining_ in_colombia_web.pdfWebber, Jeffery. 2011. From rebellion to reform in Bolivia: class struggle, indigenous liberation and the politics of Evo Morales. Chicago: Haymarket Books.

Publisher's Note Springer Nature remains neutral with regard to jurisdictional claims in published maps and institutional affiliations. 
Viviana Baraybar Hidalgo is a DPhil candidate in Politics at the University of Oxford. Her main research interest are comparative politics, political behaviour and political wrongdoing.

Eduardo Dargent is a professor of political science at Pontificia Universidad Católica del Perú. His main teaching and research interests are comparative public policy, political economy, and the state in the developing world. His book Technocracy and Democracy in Latin America (New York: CUP) was published in 2015 . 